\title{
The Tetragrammaton in Egyptian Sources - Facts and Fiction
}

\section{Background of scholarly history}

Ever since the first identification of the Tetragrammaton (Yнwh) within the onomastics of the texts from Ugarit in the 1930s, all available text corpora of the $2^{\text {nd }}$ and $1^{\text {st }}$ millennium BCE have been scrutinized for pre- or extra-biblical attestations of the Israelite divine name, YHwH. ${ }^{1}$ The rich source of foreign names attested in Egyptian script attracted attention, especially in light of the biblical Exodus-narrative with its connection to Egypt.

Appearing in 1947, Bernhard Grdseloff's² paper "Édôm, d'après les sources égyptiennes" introduced a first hieroglyphically written pretender for the Tetragrammaton into the discussion. Until 1964, the hieroglyphic writings of names Grdseloff had collected within a so-called Fremdvölkerliste in the Nubian temple at Amarah-West were the only secure attestation of an Egyptian representation of the Tetragrammaton. Then, after the publication of initial reports and copies of inscriptions from the Nubian temple of Soleb, by a comparison of the Soleb-lists with those in the temple at Amarah Raphael Giveon was able to add two further attestations. In addition, Giveon identified three further possible candidates: He introduced an attestation from the early $2^{\text {nd }}$ millennium into the discussion and pointed at two lists with names of foreign peoples and toponyms at the Ramesside temple at Medinet Habu (dated into the reign of Ramses' III.). The Egyptian evidence is insofar interesting as it antedates the second earliest attestation of the Tetragrammaton, i.e., that on the Moabite Mesha-stela, by at least 350 years.

Even though all involved authors usually point out the often rather speculative character of the YHWH-discussion, even the most bizarre localisation and etymological attempts always find a grateful audience in the neighbouring scientific disciplines. In recent times, one has to observe that the debate on the origins of the YHwH-cult has moved from referring to the primary Egyptian sources to quoting secondary literature of often doubtful standards. ${ }^{3}$ The present paper at-

1 R. S. Hess, "The Divine Name Yahweh in Late Bronze Age Sources," UF 23 (1991), 181-188.

2 B. Grdseloff, "Édôm, d'après les sources égyptiennes," Revue del l'histoire juive en Égypte 1 (1947), 69-99.

3 Thus paving the way for "parallel discussion," cf. K. Koch et al., Der Gott Israels und die Götter des Orients: Religionsgeschichtliche Studien II (FRLANT 216; Göttingen 2007), 441. 
tempts to supply the interested non-specialist reader with the current state of the art of the sources as well as of the research trying to elucidate the various and at times quite contrary opinions on them.

\section{Egyptian attestations of names associated with the Tetragrammaton}

\subsection{Biography of Khety (11 ${ }^{\text {th }}$ dynasty)}

Within the archaeological season of 1913-14, the excavators of the Theban tomb ${ }^{4}$ of a man called Khety, an overseer of the quarries, ${ }^{5}$ discovered three stelae at the tomb's outer front that were part of the external decoration. ${ }^{6}$ When Sir Alan H. Gardiner published a preliminary study of the texts in 1917, he addressed, among other details, a word he identified as a toponym, which he read "Ihuiu," and which he declared to be of "unknown" location. The respective passage of Khety's biography runs as follows:

“[1.9] (...) I returned in peace to his (the king's) palace $(c h=f)$ and brought him the best of the foreign lands in new metal from Bau(t) (3...), [1.10] shining ( $p s \underline{d})$ metal from Ihuiu

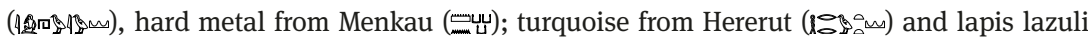
from Tefreret ( $\triangle \infty \mathrm{a})$ ), [1.11] best Saherut from the mountains, Khetauau from the mountain of Hesa/Heset (ㅆ1n); Ranetjet from Baq-[1.12] Desheret (

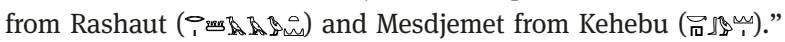

The mention of the "mine-country" (bj3, J Khety's expedition in the Sinai. ${ }^{7}$ Since Khety mentions that he delivers the commodities from Ihuiu to the "palace of Pharaoh" without giving any details whence and how he obtained these, any deliberations about the location of Ihuiu as well as the

4 According to Carnarvon's numbering tomb No. 65.

5 For the title jmy-r $\check{s}$ see W. A. Ward, Index of Egyptian administrative and religious titles of the Middle Kingdom (Beirut 1982), 47 No. 369.

6 A. H. Gardiner, "The Tomb of a Much-Travelled Theban Official," JEA 4 (1917), 29. For the architecture and especially the stela of Khety see A. Hermann, Die Stelen der thebanischen Felsgräber der 18. Dynastie (ÄF 11; Glückstadt 1940), 40 as well as F. Kampp, Die Thebanische Nekropole zum Wandel des Grabgedankens von der XVIII. bis zur XX. Dynastie (Theben XIII/1-2; Mayence 1996), 108-109 with note 517; according to Gardiner the stelae were on storage in the Cairo Museum at the time of his study.

7 E. Graefe, Untersuchungen zur Wortfamilie bj3-, Diss. phil. (Köln 1971), 35; M. Görg, "Jahwe ein Toponym?," BN 1 (1976), 182. 
other mentioned toponyms are mere speculations. ${ }^{8}$ Since then, no further attestations have been adduced that might help to locate the names of the mining areas, or the places of origin of the bartered commodities. Thus, for the toponym in question, i.e. Ihuiu, “eine Lokalisation im südpalästinischen (transjordanischen) Gebiet kann nur als möglich, keineswegs als bewiesen gelten."9

Based on comparative phonology, the land designated as ${ }^{\circ}-h^{-2}$ country in the biography of Khety can easily be eliminated from the discussion. ${ }^{10}$ Even though Egyptological conventions transcribe the initial sign by $j$, this sign does not represent a glide (i.e. /j/), but - especially in combination with the sign A2 of Gardiner's Signlist ${ }^{11}$ as in our case - the (epi)-glottal plosive /?/ (i.e. the glottal stop or Aleph). ${ }^{12}$ According to James Hoch's system of transcription, ${ }^{13}$ the whole word should be transcribed as ${ }^{\supset} a-h u^{-}{ }^{\supset} u$ country . The representation of the vowel quality, however, should be considered with utter caution. ${ }^{14}$ Previously, Edel, ${ }^{15}$ Görg, ${ }^{16}$ and Astour ${ }^{17}$ had already pointed to this fact and the equation has been rejected for other reasons by Ahituv ${ }^{18}$ and Leclant. ${ }^{19}$ Even so, Axelsson ${ }^{20}$ and Goedicke ${ }^{21}$ have reintroduced the toponym into the discussion quite unnecessarily.

8 S. Ahituv, Canaanite Toponyms in Ancient Egyptian Documents (Jerusalem 1984), actually does not exclude a connection to the Tetragrammaton, but only with the forms of the name in the Medinet Habu texts.

9 Görg, “Jahwe - ein Toponym?” (see n. 7), 182.

10 Gardiner, “Tomb” (see n. 6), 28-38, especially 36 and pl. VIII.

11 A. H. Gardiner, Egyptian Grammar, Being an Introduction to the Study of Hieroglyphs (Oxford $\left.{ }^{3} 1957\right), 442$.

12 Cf. J. E. Hoch, Semitic Words in Egyptian Texts of the New Kingdom and Third Intermediate Period (Princeton 1994), 503. The reasoning of E. A. Knauf is hence obsolete, cf E. A. Knauf, Midian: Untersuchungen zur Geschichte Palästinas und Nordarabiens am Ende des 2. Jahrtausends v. Chr. (ADPV; Wiesbaden 1988), 46 note 225.

13 Hoch, Semitic Words (see n. 12), 487-504.

14 See W. A. Ward, “A New Look at Semitic Personal Names and Loanwords in Egyptian,” CÉg 71 (1996), 41- 47.

15 E. Edel, Die Ortsnamenlisten aus dem Totentempel Amenophis III (BBB 25; Bonn 1966), 64.

16 Görg, "Jahwe - ein Toponym?" (see n. 8), 7-9, as well as idem, "YHWH - ein Toponym? Weitere Perspektiven,” BN 101 (2000), 12.

17 M. C. Astour, "Yahweh in Egyptian Topographical Lists," in Festschrift Elmar Edel (ed. M. Görg and E. Pusch; ÄAT 1; Bamberg 1979), 17-34, here 18 note 10.

18 Ahituv, Canaanite Toponyms (see n. 7), 122 note 295.

19 J. Leclant, "Le " tétragramme " à l'époque d'Aménophis III," in Near Eastern Studies dedicated to H. I. H. Prince Takahito Mikasa on the Occasion of His Seventy-Fifth Birthday (ed. M. Mori et al.; Wiesbaden 1991), 215-219, here 216 note 12.

20 L. E. Axelsson, The Lord rose up from Seir. Studies in the History and Traditions of the Negev and Southern Judah (CB.OT 25; Stockholm 1987), 60. 


\subsection{The Soleb-lists}

In the Nubian temples at Soleb and Amarah-West, a total of three lists with names of foreign places and peoples survived, containing names that have been connected with the Tetragrammaton. The oldest two attestations survived in the temple of Amenhotep III. at Soleb, dedicated to the god Amun and celebrating the so-called 'Sed festival' (Heb Sed) of the king. ${ }^{22}$ The temple's ruins were excavated between the years 1957 and 1977 by a French-Italian expedition headed by Michela Schiff Giorgini. The epigraphic documentation resided with Jean Leclant, who published parts of the names in the lists through drawings and photographs in various preliminary reports and papers. ${ }^{23}$

The first instance at Soleb is attested within a heavily destroyed list ${ }^{24}$ upon an isolated block (Sb. 69: T3 šssw $Y-h-w[\ldots]) .{ }^{25}$ Another fragment of the same list is Sb. 79 and shows the remains of $[T] 3 \breve{s} 3 s w P-y-s-p\left[\ldots . .{ }^{26}\right.$

The second instance of the Tetragrammaton at Soleb is found in the hypostyle hall (sector IV) upon column IV N4. ${ }^{27}$ The individual columns of the hypostyle hall each carry eight to ten names and each represents a specific geographic or geopolitical area of the Egyptian map of the world.

Writings of column N4 (left half $\rightarrow$ ):

21 H. Goedicke, "The Tetragram in Egyptian?," The Journal of the Society for the Study of Egyptian Antiquities 24 (1994), 24-27, here 26.

22 E. B. Porter and R. L. B. Moss, Topographical Bibliography of Ancient Egyptian Hieroglyphic Texts, Reliefs, and Paintings VII: Nubia, the Deserts, and Outside Egypt (Oxford 1995), 169-171; I. Hein, Die ramessidische Bautätigkeit in Nubien (GOF.B 22; Wiesbaden 1991), 60 -61.

23 J. Leclant, "Fouilles et travaux en Égypte et au Soudan, 1961-1962," Or. 32 (1963), 184-219, here 202-204, idem, "Fouilles et travaux en Égypte et au Soudan, 1962-1963," Or. 33 (1964), 337-404, here 383-385, idem, "Les fouilles de Soleb (Nubie soudanaise), quelques remarques sur les écussons des peuples envoûtés de la salle hypostyle du secteur IV,” in: Göttinger Vorträge (NAWG.PH 13; Göttingen 1965), 205-216.

24 M. Schiff Giorgini and C. Robichon, Soleb 3: Le temple-description; préparé et éd. par Nathalie Beaux (Bibliothèque générale 23; Cairo: 2002), 179 sowie M. Schiff Giorginia and C. Robichon, Soleb 5: Le temple-bas-reliefs et inscriptions; préparé et éd. par Nathalie Beaux (Bibliothèque générale 19; Cairo 1998), pl. 206-207.

25 Leclant, "Fouilles et travaux 1961-62," (see n. 23), 203 note 3.

26 The initial publication of Leclant, "Les fouilles de Soleb” (see n. 23), 215 fig. f, shows still the probably correct sign form with the rectangular $p$-seat (Gardiner, Sign-List: Q3) and the head of the alighting duck. In the later publications of the block the sign has been altered in such a way that it now resembles the $g$-jar stand (Gardiner, Sign-List: W11). Also the form of the back wing of the $p$ 3-bird has been deformed in such a way that it looks like a logographic stroke.

27 Schiff Giorgini and Robichon, Soleb 5 (see n. 24), pl. 221. 


$\begin{array}{lll}\alpha 1 & T 3 \check{s} 3 s w T-r-b-r \\ \alpha 2 & T 3 \check{s} 3 s w Y-h-w^{28} \\ \alpha 3 & T 3 \check{s} 3 s w s-m-t^{29} \\ \alpha 4-\ldots & \text { destroyed } & \text { (destroyed) }\end{array}$

Writings of column N4 (right half $\leftarrow$ ):

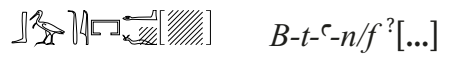

$\beta 2-\ldots$ destroyed

(destroyed)

Due to the extensive gaps in the list, owing to its preservation and its different sequence of names compared to other lists, the internal organisation of the Soleb-list could so far not be cleared..$^{30}$ The picture is complicated by the fact that each column contains two mirrored partial lists resulting in various mistakes of the sculptors during the transfer from the template onto the correct side of the column. Therefore, the original sequence of the place names has been disturbed ${ }^{31}$ and thus the Soleb-list, even though closer to the "Urliste", must make way for the later lists at Amarah-West and Aksha in reconstructing the sequence. Already in one in his preliminary papers Leclant made aware of the parallelism between these lists (treated in the following section) and the Soleb one. ${ }^{32}$

28 Represented erroneously with the Aleph-vulture in Ahituv, Canaanite Toponyms (see n. 8), 121. The initial copy of Leclant, "Les fouilles de Soleb" (see n. 23), Fig. c. shows distinctly the quail-chick as lowermost sign (thus, also in R. Giveon, Les Bédouins Shosou des documents Égyptiens [DMOA 18; Leiden 1971], 26 Doc. 6a).

29 The representation (with D37 of Gardiner, Sign-List) in Ahituv, Canaanite Toponyms (see n. 8), 177 has to be corrected accordingly (cf. Schiff Giorgini and Robichon, Soleb 5 (see n. 24), pl. 221).

30 Cf. the reconstruction in W. Helck, Die Beziehungen Ägyptens zu Vorderasien im 3. und 2. Jahrtausend v.Chr. (ÄA 5; Wiesbaden ${ }^{2} 1971$ ), 264-266 and E. Edel, "Die Ortsnamenlisten in den Tempeln von Aksha, Amarah und Soleb im Sudan,” BN 11 (1980), 64 (with schematic representation). Helck's hypothesis that the position of column N IV was the last within the sequence of the northern half of the hypostyle hall is based solely on the assumption the names it contains must belong to the "desert of southern Palestine" (266).

31 Cf. N.-C. Grimal, Civilisation pharaonique: archéologie, philologie, histoire. Les Egyptiens et la géographie du monde (online publication; Paris 2003), 721, 723.

32 J. Leclant, "Fouilles et travaux en Égypte et au Soudan, 1960-1961," Or. 31 (1962), 328 n. 4 and "Fouilles et travaux 1961-1962" (see n. 23), 203 note 2; for earlier literature see cf R. Giveon, “Toponymes ouest-asiatiques à Soleb,” VT 14 (1964), 239-255, here 239, Note 1. 


\subsection{The lists of Amarah-West}

Approximately $50 \mathrm{~km}$ north of Soleb lie the settlement and its adjacent temple of Amarah-West. ${ }^{33}$ The temple of Ramesses II. had been excavated by the English archaeologist Herbert Fairman on behalf of the Egypt Exploration Fund in the years 1938 and 1939, as well as between 1947 and 1950, and was the topic of various preliminary reports. The inner walls of the eastern half of the temple's peristyle is decorated in the lower part with an extensive list of northern peoples and place names.

Even though the first volume of the Amarah-West edition (The architectural report) contains a large amount of results as well as images taken from Fairman's legacy, ${ }^{34}$ the proper epigraphic documentation and publication is still lacking. So far, the texts are available only in Kenneth A. Kitchen's handwritten copies in his "Ramesside Inscriptions." 35

Hieroglyphic writings (northern wall, east of the gate $\leftarrow$ ):

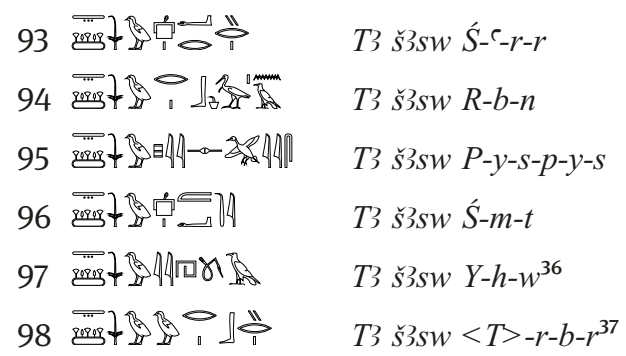

33 Hein, Ramessidische Bautätigkeit (see n. 22), 51-52, Tafel 17.

34 P. Spencer, Amara West I: The architectural report. With contributions by P.L. Shinnie, F.C. Fraser and H.W. Parker (MEES 63; London 1997).

35 Porter/Moss, Topographical Bibliography VII (see n. 22), 161 (24)-(27) as well as (29)-(31); K. A. Kitchen, Ramesside Inscriptions II (Oxford 1979), 215-217.

36 See Kitchen, Ramesside Inscriptions II (see n. 37), 217 (10). The assumed change from the sign $w 3$ to the sign actually read as $r w d / 3 r / 3 j$ can be easily explained as a copy error from a hieratic template, see Görg, "Jahwe - ein Toponym?” (see n. 7), 185. The Soleb-list shows a quail chick (read $w$ ) at the end of the name instead of a vulture (read 3) but an alike emendation seems easily possible. Görg, "Jahwe - ein Toponym?” (see n. 7), 185, considered this as unlikely since the scribe of the Amarah-list otherwise displays no difficulties in discriminating between the Alephsign and the w-quail chicken. In Görg, "YHWH - ein Toponym?” (see n. 7 and 16), 11 Görg refers to an opinion expressed by Elmar Edel: Edel transferred his analysis of the scribal mistakes in the list of African place names of Thutmosis III. to our list and concluded that "natürliche Lesung $Y-h-w^{3}-3$ anzusetzen sei" (the natural reading should be $\left.Y-h-w^{3}-3\right)$. 


\section{Commentary:}

(93) The starting point of all identification and localisation attempts made hitherto for the Shasu-names, especially the $Y-h-w$ one, is the first name of the Shasu sequence at Amarah-West: $S^{-} e_{-} r-r .{ }^{38}$ Assuming that this equates with the otherwise also in New Kingdom texts attested "Sëir," we would at least be able to recognize one name of the Shasu sequence. Proceeding from there, i.e. that Egyptian $S^{-}-r-r$ is identical with the Old Testament place name Sëir (or Mount Sëir), one might further assume that the whole Shasu sequence can be located in southern Palestine or the Edomite realm. ${ }^{39}$

As later researchers ${ }^{40}$ pointed out correctly, this line of argument developed by Grdseloff is circular: Since YHwH's origin is, according to the Old Testament, in the Kenite-Edomite area, the $S_{-}-{ }_{-} r-r$ of the Amarah-list must be identical with the biblical Sëir. The mention of Sëir on the other hand proves YHwh's descent from the southern Palestine area (Edom). ${ }^{41}$ To establish the identification be-

37 Giveon, "Toponymes," (see n. 32), 244 refers to the reading of B. Grdseloff and corrects the latter's irbir to twrbir, since in the list ETL XXVII (Medinet Habu) the number $116(T-w-r)$ appears next to $Y-h-3$ (No. 115).

38 At first in Grdseloff, “Édôm” (see n. 2), 79-80; M. Weippert, Edom. Studien und Materialien zur Geschichte der Edomiter auf Grund schriftlicher und archäologischer Quellen (Diss. Tübingen 1971), 31; idem, "Semitische Nomaden des zweiten Jahrtausends. Über die Š3św der ägyptischen Quellen,” Biblica 55 (1974), 265-280, here 270 - 271; M. Görg, "Jahwe - ein Toponym?” (see n. 7), 12-13 Anm. 34; E. A. Knauf, Midian (see n. 12), 50-51.

39 See for instance K.A. Kitchen, “The Egyptian Evidence on Ancient Jordan," in Early Edom and Moab. The Beginning of the Iron Age in Southern Jordan (ed. P. Bienkowski; SAM 7; Sheffield 1992), Fig. 3.2. The majority of the more recent biblical scholarly/exegetic literature adheres to this line of reasoning (see e.g. J. Day, In search of pre-exilic Israel. Proceedings of the Oxford Old Testament seminar [JSOT.S 406; London et al. 2006], 50-51). The basic assumption is that the first name in the sequence works as a headline (Leittoponym) for the following place names, a system to be seen in the lists on the statue bases from Kom el-Hettân (see E.Edel and M. Görg, Die Ortsnamenlisten im nördlichen Säulenhof des Totentempels Amenophis' III. [ÄAT 50; Wiesbaden 2005], 45).

40 At first in Astour, "Yahweh in Egyptian Topographical Lists" (see n. 17), 21.

41 Similarly S. Herrmann, "Der alttestamentliche Gottesname," in Gesammelte Studien zur Geschichte und Theologie des Alten Testaments (ed. S. Herrmann; TB 75; München 1986), 76-88 and more recently T. Schneider, "The first documented occurence of the God Yahweh? (Book of the Dead Princeton “Roll 5”)," JANE 7 (2008), 113-120, here 114 as well as M. Leuenberger, "Jhwhs Herkunft aus dem Süden. Archäologische Befunde - biblische Überlieferungen - historische Korrelationen," ZAW 122 (2010), 1-19, here 4-8 reprinted in: M. Leuenberger, Gott in Bewegung. Religions- und theologiegeschichtliche Beiträge zu Gottesvorstellungen im alten Israel (FAT 76; Tübingen 2011), 14-22. 
tween $S^{-}$- $_{-} r-r$ and Sëir, Grdseloff and those scholars following him, ${ }^{42}$ have to explain the hieroglyphic writing of the name in the Amarah-West list as an error for $S$ - ${ }_{-} r$ or as "common" duplication of the $r_{0}{ }^{43}$

While the identification of the single graphemes with the assumed phonemes poses no problem at all (Egyptian $\langle s\rangle=$ Semitic $s / s /$; Egyptian $\left\langle^{c}\right\rangle=$ Semitic /§/; Egyptian $\langle r\rangle=$ Semitic $/ r /{ }^{44}$ ), the equation of the whole complex carries the problem that $<\mathrm{r}>$ appears graphically twice. Grdseloff ${ }^{45}$ emended this to $s_{-}{ }^{-} r$ based on Ramesside inscriptions and texts mentioning a tribe/people called $s-{ }^{-}$$r^{46}$ or a similarly written place name. ${ }^{47}$ He assumed the first $\langle r\rangle$ to be a mistake for the sign 3 of the hieratic template. Weippert ${ }^{48}$ used a similar explanation by identifying the supposedly wrongly written sign as an original book roll sign. Görg ${ }^{49}$ finally reasoned that the whole double $\langle r\rangle$-writing should be considered a graphic peculiarity of the Ramesside writing system showing this feature more often. The latter is indeed a well-known phenomenon ${ }^{50}$ and is usually expressed by two $<r>$-graphemes positioned one above the other, with the lower marked in addition by an ideographic stroke. The whole group serves to express graphically the fact that the rhotic sound was retained. ${ }^{51}$ In our case, however, the last group consists of a combination of a double stroke, an $\langle r\rangle$ and a stroke. This group is typically used if a syllable final rhotic sound had to be expressed. According to

42 M. Weippert, "Semitische Nomaden des zweiten Jahrtausends" (see n. 38), 271 note 1.

43 See Görg, “Jahwe - ein Toponym?,” (see n. 7), 185 note 34 with instances supposedly proving his interpretation as duplication.

44 Which rhotic phoneme actually is represented by the sign is irrelevant for our question; Egyptian might have had at least two different rhotic sounds, cf. M. Müller, “Ägyptische Phonologie? Möglichkeiten und Grenzen linguistischer Modelle bei der Beschreibung des Lautsystems einer extinkten Sprache," in Methodik und Didaktik in der Ägyptologie. Herausforderungen eines kulturwissenschaftlichen Paradigmenwechsels in den Altertumswissenschaften (ed. A. Verbovsek et al.; Ägyptologie und Kulturwissenschaften IV; München 2011), 509-531, here 519.

45 Grdseloff, "Édôm," (see n. 2), 79-80.

46 Thus, for instance in the Great Harris Papyrus (pHarris I 76,9-10): "I smote the $\hat{S}-\mathrm{c}_{-} r$ from the Shasu tribe” cf. P. Grandet, Le Papyrus Harris I (BEt 109; Kairo ²005), 337 (vol. I) and 243-245 (vol. II).

47 As $\underline{d} w n-\hat{S}_{-} \mathrm{c}_{-} r$ in an epithet of Ramesses II. upon a column at Tanis ("savage wild lion who seized the Shasu and hacked up the mountain of $S$ - $-_{-} r$ with his strong arm/sword”), see Kitchen, Ramesside Inscriptions II (see n. 36), 408,16-409,1.

48 Weippert, "Semitische Nomaden des zweiten Jahrtausends" (see n. 38), 271 note 1.

49 Görg, “Jahwe - ein Toponym?” (see n. 7), 12 note 34.

50 See e.g. A. Erman, Neuägyptische Grammatik (Leipzig ${ }^{2} 1933$ ), §§48-51; F. Junge, Neuägyptisch. Einführung in die Grammatik (Wiesbaden $\left.{ }^{3} 2008\right), 34-35$.

51 The rhotic approximant / $\mathrm{x} /$ of Egyptian disappears in syllable final position. If $/ \mathrm{x} /$ is retained in the onset of the syllable this fact is marked graphically via the mentioned double writing. 
the evidence gathered by Hoch, this group does always represent an actually realised rhotic phoneme..$^{52}$ Thus, the assumption of a double graphic representation would be highly redundant.

Graphemic problems result also from the other explanations and emendations. Even though the complementation of bi- or tri-consonantal signs is rather common in the Egyptian writing system, but - especially with $3^{53}$ - in Ramesside times, rather by the succeeding than the preceding consonant. In those cases in which the initial consonants appear, it follows the sign $3 .^{54}$ Therefore, Grdseloff' ${ }^{55}$ emendation would result in a combination which - to put it positively would be unusual and hence, would be no real improvement compared to the actual writing.

Similar problems arise from Weippert's ${ }^{56}$ emendation of the book roll sign beneath the sign $\langle>$ : Even though attested as the graphemic complement of ?, within the system of group writing, simple $<>$ is not used alone, ${ }^{57}$ and appears only with complementing on $\langle y\rangle$ or $\langle w\rangle$. Thus again, the emendation results in no improvement compared to the actual writing.

Hence, one cannot but state that the list at Amarah contains a place name with the consonants $S_{-}-_{-} r-r$, definitely more than necessary for an equation with the Mount Sëir. If one would insist on this equation, one would have to look for an emendation that would reduce the amount of rhotic graphemes. Otherwise, one cannot but look for a place name that suits the attested writing better (see Astour's suggestion below).

(94) According to Grdseloff, the name $R-b-n$ should be equated with the Transjordanian Laban (Deut 1:1) = Libnah (Num 33:20 - 21). ${ }^{58}$ Giveon refers to "Libona, l'actuel Khirbet el Libben, au sud d'Amman." Ahituv ${ }^{59}$ and Wilson ${ }^{60}$ sug-

52 Hoch, Semitic Words (see n. 12), 509; see also the latter's analysis Hoch, Semitic Words (see n. 12), 407.

53 Also with other horizontally arranged bi- or tri-consonantal signs. The use of initial consonants is more common with vertically arranged signs.

54 See the writings of the various lemmata 3 (and derivations) in Wörterbuch der aegyptischen Sprache I (ed. A. Erman and H. Grapow; Berlin 1926), 161-168; see also the use of $~ \Im$ in the system of group writing in Th. Schneider, Asiatische Personennamen in ägyptischen Quellen des Neuen Reiches (OBO 114; Fribourg and Göttingen 1992), 370.

55 Grdseloff, "Édôm” (see n. 2), 79-80.

56 Weippert, "Semitische Nomaden des zweiten Jahrtausends" (see n. 38), 271 note 1.

57 See Th. Schneider, Asiatische Personennamen (see n. 54), 369-370.

58 Grdseloff, "Édôm” (see n. 2), 80. Cf. Ahituv, Canaanite Toponyms (see n. 8), 129.

59 Ahituv, Canaanite Toponyms (see n. 8), 129.

60 K.A. Wilson, The Campaign of Pharaoh Shoshenq I into Palestine (FAT 9/II; Tübigen 2005), 133. 
gested Tell Abu Seleimeh behind esh-Sheikh Zuweid. From the phonological point of view nothing speaks against the equation with Laban nor with Libona.

(95) Görg suggested for the name $P-y-s-p-y-s$ a connection to the name Nāpiš, a son Ismael's (Gen 25:15; 1 Chr 5:19). ${ }^{61}$ He furthermore suggested, confirmed by Edel, ${ }^{62}$ that the duplicated writing of an absolutely used possessive pronoun, had been used to represent the place name.Thus, the name could have been vocalized as Paspas. Grdseloff assumed a connection to Semitic bisbâs "muscadier" or to the meaning "coloured" which he connected with the Beduin habit to colour their tents.

(96) Grdseloff saw in the name $S$ - $m-t$ a "gentilice" (designation of a race) which he equated with the Biblical Shimatites (1 Chr 2:55). These he identified with the Kenites and hence part of the nomadic groups of the Arabah (biblical Sëir). ${ }^{63}$ Weippert assumed to identify them as the tribe Šammāh (Gen 36:13, 17). ${ }^{64}$ However, as Anson F. Rainey's pointed out, the Egyptian grapheme $<\mathrm{S}>$ is never used to represent the Semitic post-alveolar fricative $/ \int /$ in secure equations. ${ }^{65}$

(97) According to Grdseloff, this represents "incontestably" the name "Jahwă." He felt confirmed in the reading of the first two signs by the Late Period instance $p 3-t 3-(n)-y h t$ (stele Berlin 1107), which he interprets as "la terre de Jahoud." ${ }^{66}$ He assumed an Edomite locality but confessed that "il nous manque encore tous les éléments" for a specific localisation. Yet based on the biblical context he is rather confident that this "ville de Jahwă" must have been a "centre kénite" ("il n’y a pas de doute que notre localité édômite portait d'après notre source qui date du règne de Ramsès II (...) le nom sacré du dieu des Israélites"). ${ }^{67}$ Giveon followed Grdseloff in that issue and read "Yahwe en terre de Shosou." For

61 Görg, "Jahwe - ein Toponym?," (see n. 7), 186 assumed a "eine reduplizierte Bildung des Stamnes NPŠ ("zahlreich sein")." Thus suggestion has been rejected by Ahituv, Canaanite Toponyms (see n. 8), 155 without further discussion.

62 Edel, "Die Ortsnamenlisten” (see n. 30), 78.

63 Giveon, “Toponymes ouest-asiatiques à Soleb” (see n. 32), 244 refers to the place name $S$ - $m-y$ in the list ETL XXVII, 39 (Ramesses III.), although without drawing any further conclusions: "Samat et Pyspys sont inconnus" (Giveon, “Toponymes ouest-asiatiques à Soleb” [see n. 32], 245). 64 See Weippert, "Semitische Nomaden des zweiten Jahrtausends” (see n. 38), 271.

65 A. Rainey, "Review of Hoch, Semitic Words," IOS 18 (1998), 431-453, here 452.

66 Grdseloff, "Édôm” (see n. 2), 81. This goes back to Sethe who, however, has not been able to substantiate his assumption further, see K. Sethe, Spuren der Perserherrschaft in der späteren ägyptischen Sprache (NGWG.PH; Berlin 1916), 128-129.

67 Grdseloff, "Édôm” (see n. 2), 82. 
him the identity of the place name written in Egyptian and the name of the Israelite deity is certain: "Le nom est le tétragramme."68

(98) Grdseloff knew only the defective writing from Soleb and identified the place hence with Arbela, a place to the east of the Tigris river (ancient Urbilum, nowadays Irbil/Arbil). In addition, he suggested a place called Irbid in Transjordan (Beth-Arbel). ${ }^{69}$ Giveon corrected Grdseloff's $W-r-b-r$ to $<T>-r-b-r$, since the list ETL XXVII (Medinet Habu) shows under \#116 the name $T-w-r$ close to the name $Y-h-3(\# 115) .^{70}$

In his analysis of the lists at Soleb, Amarah-West, and Akscha, Edel ${ }^{71}$ was able to show that, despite their different direct templates, all three of these lists go back to a single "Urliste", the sequence of which can be reconstructed according to the sequence of the Amarah-list. ${ }^{72}$ Confronting the Soleb- with the Amarah-list (see table 1), shows that the scribe of the Soleb-list placed the Shasu-sequence in reversed order, and that his template must have contained at least one further name ( $\beta 1$ Beth-Anath?) which was omitted at Amarah-West.

Despite the considerable uncertainties in the identification and localisation of the names in the Soleb- and Amarah-lists, and the numerous premises necessary to assume localities in southern Palestine or the Transjordan area, most scholars accept the southern location based on the identification of Sëir (Amarah-list \#92). ${ }^{73}$ However, this interpretation is not without alternative, as a further list with names shows, in which the Tetragrammaton is assumed to appear.

\subsection{The Medinet Habu-lists (20 ${ }^{\text {th }}$ dynasty)}

As early as 1964, Giveon referred to possible parallels of the writings of the Shasu-sequence at Soleb and Amarah-West in the great list of Ramesses III. at

68 Giveon, Bédouins Shosou (see n. 28), 26-27; similarly in W. Helck, "Die Bedrohung Palästinas durch einwandernde Gruppen am Ende der 18. und am Anfang der 19. Dynastie," VT 18 (1968), 472-480, here 477-478. ("Die Lokalisierung dieser einzelnen Landschaften ist bisher nicht möglich, was besonders wegen der Landschaft Jahwe wichtig wäre, weil doch sicherlich ihr Gott von den Israeliten zu ihrem Gott gemacht worden ist").

69 Grdseloff, "Édôm” (see n. 2), 82-83.

70 Giveon, “Toponymes ouest-asiatiques à Soleb” (see n. 32), 244.

71 Since the list at Aksha (Ramesses II.) ends with \#29, it cannot be used in this issue (thus also Edel, "Die Ortsnamenlisten" [see n. 30], 64).

72 See Edel, "Die Ortsnamenlisten” (see n. 30).

73 See Görg, “Jahwe - ein Toponym?” (see n. 7), 185: “Mit einem gewissen Grad an Wahrscheinlichkeit lassen sich die Namen in Transjordanien und Südpalästina lokalisieren.” 
the $1^{\text {st }}$ pylon at Medinet Habu. ${ }^{74}$ This list at the southern tower of the $1^{\text {st }}$ pylon preserves 125 cartouches with names. These names are divided according to their geographic distribution and their sources into three groups. ${ }^{75}$ Group I consists of the names 1-69 with names from northern Mesopotamia from the Transtigris area. ${ }^{76}$ According to Michael Astour, this list can be traced back to a list of Thutmosis III. Group II with the names 76-94 and 98-110 is a copy of a list of Ramesses II. at Karnak, only with their order reversed. ${ }^{77}$ Group III with the numbers 70-75 and 111-121 should be traced back, according to Astour, to a nowadays lost list of Ramesses II. Within this third group, one finds as number 115 the place name $Y-h 4 M \sim r\left({ }^{78}\right.$ which Giveon originally connected with the $Y-h-w$ writings at Amarah-West and Soleb. ${ }^{79}$

The identification and localisation of the names of this third group in which the supposed Tetragrammaton-writing $Y-h$ appears is difficult, in want of parallels. Giveon suggests for \#116 a connection to the $T-r-b-r$ of the Soleb-list. ${ }^{80} \mathrm{Görg}$ wanted to connect "at least the names 111-112" with places in southern Palestine, ${ }^{81}$ and posed the question whether two separate names might hide behind the writing $T-w-r-b-r$ in the Soleb- and the Amarah-list. For this, he refers to \#112 (list XXVII) naming a place $B-w-r / B-r$ that could be complemented with \#116 T-w-r to yield the Soleb-name. Görg thought to identify in \#112 the element br "well." In addition, he suggested to associate $T-w-r$ (\#116) with the Itureans. ${ }^{82}$

74 Giveon connected Soleb N IV $\alpha 1 T-r-b-r$ with ETL XXVII \#116, Soleb N IV $\alpha 2 Y-h-w$ with ETL XXVII, \#115 and XXIX, \#13 ( $Y$ - $h)$. Soleb N IV $\alpha 3$ ś-m-t with ETL XXVII, \#39.

75 Astour, "Yahweh in Egyptian Topographical Lists" (see n. 17), 24.

76 M.C. Astour, "Mesopotamian and Transtigridian Place Names in the Medinet Habu Lists of Ramses III,” JAOS 88 (1968), 733-752, here 733-734.

77 Helck, Beziehungen (see n. 30), 237

78 J. Leclant's refusal of this additional possible instance of the Tetragrammaton is left without explanation (cf Leclant, "Le "tetragramme"” [see n. 19], 216 with note 12).

79 Giveon, “Toponymes ouest-asiatiques à Soleb” (see n. 32), 244. The sign Z4 (Gardiner, SignList) has according to Görg, "Jahwe - ein Toponym?” (see n. 7), 186 “lediglich ornamentale Funktion" (merely ornamental function). Also the Aleph-sign of the final group is considered by Görg as "entwertet/indifferent" (devalued/indifferent) in its vocalic reference. The identical writing reappears in a short list at the $1^{\text {st }}$ pylon of Medinet Habu (J. J. Simons, Handbook for the Study of Egyptian Topographical Lists relating to Western Asia [Leiden 1937], list XXIX, \#13). However, as the latter list seems nothing but a random collection of names taken from the larger list, the latter reference is of no relevance in the present discussion.

80 Giveon, "Toponymes ouest-asiatiques à Soleb” (see n. 32), 244.

81 Görg, “Jahwe - ein Toponym?” (see n. 7).

82 Sons of Ismael according to the OT tradition (Gen 25:15; 1 Chr 1:31); see Görg, "Jahwe - ein Toponym?” (see n. 7), 186-187. Görg carries on with additional prosopographic identifications: Thus he wants to recognize in \#111 (rwjr) the biblical name Reūel, a son of Esau (1 Chr 1:35, 37) 
A completely different track was followed in Michael C. Astour's work of $1964:{ }^{83}$ Ignoring the conceived wisdom of the Sëir-identification, seeing $Y$ - $h$ neutral as a geographical name, and disregarding the Old Testament tradition of a southern origin of the YнwH cult, he extended the geographic realm of possible candidates into the whole Syrian-Palestinian area. Thus, Astour was able to present identifications with topo- or oronymes in the northern Palestinian and Lebanese area for most of the names in the third group of the Medinet Habu-list.

Further confirmation to Astour's reconstruction is possibly added by the Solebname $\beta 1$, which is positioned in opposite direction to the Shasu-sequence on the column N IV, and which can be reconstructed with Edel as BethAnath. ${ }^{84}$ The close proximity of this name with a list of southern Palestinian mountain areas seems of limited plausibility. The same must be said for the mention of Ginti-Kirmil (Amarah-list \#98) directly following the Shasu-sequence. Both place names, disregarded by the majority of scholars dealing with the Shasu-sequence, do speak in favour of Astour's suggestions, particularly since the place Ginti-Kirmil is connected to Sëir in another context (EA 288,26; 289,18). ${ }^{85}$

The identification of the name 'Ain Shasu in a list of Amenhotep III. at Kom el-Hettân, ${ }^{86}$ and the Palestine-list of Thutmosis III. ${ }^{87}$ at Karnak by Rainey ${ }^{88}$ and

(see also Weippert's suggestion to connect smt with Shamma, the son of Reūel, in: Weippert, "Semitische Nomaden des zweiten Jahrtausends" [see n. 38], 271-272). The \#122 (krn) reminded him of Kerān (Gen 36:26; 1 Chr 1:41), also connected to Sëir. A similar genealogical connection Görg proposed already for the name Pyspys by connecting it to Nāpišs, being in turn a son of Ismael (see above).

83 Astour, "Mesopotamian and Transtigridian Place Names" (see n. 76).

84 The reading is refused by Ahituv, Canaanite Toponyms (see n. 8), 75 Anm. 105a. Instead the name should be read as Beth- $f y$ (?). And indeed the copy in Schiff Giorgini and Robichon, Soleb 5 (see n. 24), pl. 221 shows instead of the expected $n$ the head of a $f$-viper. Our photographic documentation did not confirm this though since the surface is severely damaged in this area. Elusive is also the description of Schiff Giorgini and Robichon, Soleb 3 (see n. 24), 123 of the cartouche as "presque intact," even though the lower third is destroyed. Our images show traces in the lower part of the cartouche that might have been part of the throw-stick-sign typically used to mark foreign place names (Gardiner, Sign-List: N25) which have not been noted in the publication. The inaccuracy of the drawings of the Soleb-list (in Schiff Giorgini and Robichon, Soleb 5 [see n. 24]) is as deplorable as the fact that damages and breaks are never properly marked.

85 For the reading and identification see Edel, "Die Ortsnamenlisten," (see n. 30), 78.

86 Edel, Ortsnamenlisten (see n. 15), 25 as well as Edel and Görg, Ortsnamenlisten (see n. 39), 106.

87 Simons, Handbook (see n. 79), 111 (Liste I, 5). 
Weippert, ${ }^{89}$ proved that the Shasu-groups operated also far to the north within northern Palestinian territory. The mentioned 'Ain Shasu can be located with all probability in the Lebanese Biqā, which in return adds further weight to Astour's suggestions. ${ }^{90}$

\begin{tabular}{|c|c|c|c|c|}
\hline $\begin{array}{l}\text { ETL I } \\
\text { (T III.) }\end{array}$ & $\begin{array}{l}\text { Soleb } \\
\text { (A. III.) }\end{array}$ & $\begin{array}{l}\text { Amarah-West } \\
\text { (R. II.) }\end{array}$ & $\begin{array}{l}\text { ETL XXVII } \\
\text { (R. III.) }\end{array}$ & $\begin{array}{l}\text { Identification } \\
\text { acc. to Astour (1979) }\end{array}$ \\
\hline (337) $\breve{S}-e_{-r} r-r$ & - & (92) $S_{-}-c_{-r-r}$ & - & Šehlal (?) \\
\hline- & - & - & (70) $H-r-n-m$ & Hirmil (at Orontes) \\
\hline (10) $R-b-n$ & - & (93) $R-b-n$ & (71) $R-b-n-t$ & Labana \\
\hline- & - & - & (72) $B-t-d-q-n$ & Daqqun/Dqun \\
\hline- & - & - & (73) Q-r-b-q & 'Ayn al-Baqq \\
\hline- & - & - & (74) $K-r-m-y-m$ & not identified \\
\hline \multirow[t]{12}{*}{ (73) $\check{S}-b-t-n$} & - & - & (75) $\check{S}-b-d-n$ & Riblah \\
\hline & $P-y-s-p[\ldots]^{91}$ & (94) $P-y-s-p-y-s$ & - & 'Ayn Fišfiš \\
\hline & $\alpha 3 S-m-t$ & (95) $S-m-t$ & -92 & Šāmāt \\
\hline & - & - & (111) $R-w-j-r$ & Lawiyah/Galmidun \\
\hline & - & - & $(112)$ & see below \\
\hline & - & - & (113) Q-m-q & Ḍahr/Wadi al-Ğimmāqah \\
\hline & - & - & (114) Q-b-r-c & Ḍuhūr Qa'būrā \\
\hline & $\alpha 2 Y-h-w$ & (96) $Y-h-3$ & $(115) Y-h$ & not identified \\
\hline & $\alpha 1 T-r-b-r$ & $(97)<T>w-r-b-r$ & $\begin{array}{l}(116)+(112) \\
T-r B-r\end{array}$ & (Gabal) Turbul \\
\hline & - & - & (117) $S_{-}-n-n-r$ & Sanir \\
\hline & - & - & (118) $M-n-d-r$ & Mandarah \\
\hline & - & - & (119) $\underline{D}-b-b$ & Dabbābīyah \\
\hline
\end{tabular}

88 A. F. Rainey, ${ }^{2}$ EAT.S, 91; idem, "El- ${ }^{c}$ Amarna Notes," UF 6 (1974), 297; idem, “Toponymic Problems," Tel Aviv 2 (1975), 13-14.

89 M. Weippert, "Die Nomadenquelle. Ein Beitrag zur Topographie der Biqā' im 2. Jahrtausend v.Chr.," in Archäologie und Altes Testament. Festschrift für Kurt Galling zum 8. Januar 1970 (ed. A. Kuschke and E. Kutsch; Tübingen 1970), 259-272, here 263-265; Weippert, "Semitische Nomaden des zweiten Jahrtausends" (see n. 38), 273.

90 A further possible case has been described in M. Görg, "Thutmosis III. und die š3św-Region," JNES 38 (1979), 199-202, here 201-202. Against this identification and localisation of the "well of the nomads" E. Lipiński, On the skirts of Canaan in the Iron Age: historical and topographical researches (OLA 153; Leuven et al. 2006), 362-363, raised some rather weak and altogether unconvincing counterarguments. Astour's reconstruction has been accepted by J. C. de Moor, The Rise of Yahwism: The Roots of Israelite Monotheism (BEThL XCI; Leuven 1990), 112 with note 51. The northern localisation of the place names was dismissed out of hand rather ex cathedra by Axelsson, The Lord rose up (see n. 20) and Knauf, Midian (see n. 12), 46-47.

91 Attestedin Sb.II 69.

92 Giveon, “Toponymes ouest-asiatiques à Soleb” (see n. 32), 244 refers here to $S-m-y$ (\#39) of the list ETL XXVII (Medinet Habu). 
Continued

\begin{tabular}{|c|c|c|c|c|}
\hline $\begin{array}{l}\text { ETL I } \\
(T \text { III.) }\end{array}$ & $\begin{array}{l}\text { Soleb } \\
\text { (A. III.) }\end{array}$ & $\begin{array}{l}\text { Amarah-West } \\
\text { (R. II.) }\end{array}$ & $\begin{array}{l}\text { ETL XXVII } \\
\text { (R. III.) }\end{array}$ & $\begin{array}{l}\text { Identification } \\
\text { acc. to Astour (1979) }\end{array}$ \\
\hline (122) $I-m-t$ & $\begin{array}{l}- \\
-\end{array}$ & $\begin{array}{l}- \\
-\end{array}$ & $\begin{array}{l}\text { (120) } I-m-t \\
(121) D-w-r\end{array}$ & $\begin{array}{l}\text { Hamath (Ḥamāh) } \\
\text { Tyrus }\end{array}$ \\
\hline $\begin{array}{l}(97) \\
B-t-i-n-t\end{array}$ & $\beta 1 B-t^{c}-[n-t]$ & - & - & Beth Anath \\
\hline- & $\beta 2[$ & $\begin{array}{l}\text { (98) } \\
\text { Q-n-t-k-3-m-r }\end{array}$ & - & - \\
\hline- & $\begin{array}{l}\beta 3[ \\
\beta 4[\end{array}$ & $\begin{array}{l}\text { (99) Q-?-s } \\
(100) M-t-c_{-} w\end{array}$ & $\begin{array}{l}- \\
-\end{array}$ & - \\
\hline
\end{tabular}

table 1: Sequences of names discussed from the lists of Thutmosis III. (ETL I), Amenhotep III. (Soleb), Ramesses II. (Amarah-West), and Ramesses III. (Theben-West, Medinet Habu) in synopsis with the respective identifications (after M.C. Astour, in: FS. Edel (see n. 18), 17-34)

Astour's suggestions to locate the place names of the Shasu-sequence from the Soleb- and Amarah-lists in northern Palestine do not exclude their presence in the southern (biblical Edomite) area in the $18^{\text {th }}$ dynasty. The Shasu's sphere of action is just extended significantly to the north to achieve a better consistency with the information supplied by the contemporary Egyptian sources. Thus, Görg's suggested localisation of the place name $T 3$ ? $3^{3}$ ? sw P3-wnw in the Amarah-list (\#45) retains a certain plausibility, as both Edel and Görg showed convincingly that the name hides behind the rather peculiar writing. Whether this toponym actually belongs - despite its position in the list - to the Shasusequence (Amarah-West \#93-97), and thus to the same geographical horizon, still remains uncertain at present. Görg opted for a connection with the Edomite mining centre פוּנ Punon (modern Feinan). ${ }^{93}$

Recently, Manfred Görg introduced a further interpretation of the "Egyptian" Shasu-names by connecting them with (Hebrew) designations of animals or colour terms, suggesting to consider these as tribal names. ${ }^{94}$

Unlike with the above discussed and dismissed instance from the $11^{\text {th }}$ dynasty biography of Kheti, no grapho-phonetic obstacles speak against an identifica-

93 M. Görg, "Punon - ein weiterer Distrikt der š3św-Beduinen?,” BN 19 (1982), 15-21, here 19. 94 Görg, "YHWH - ein Toponym?" (see n. 7 and 16). Sëir would then not only be a place name but also the designation of the he-goat, the Shasu-name $P-y-s-p-y-s$ was connected by Görg with the Akkadian paspasu "duck," and for $R-b-n$ he referred to Hebrew laban "white," probably connected to the colour of an animal's hide. Accordingly, he connected $S-m-t$ with the Akkadian word sāmtu "redness." Görg suggested also for $T-r-b-r$ a connection to animals (srbl "cock's comb”). 
tion of the writing $y$ - $h$-w, that is attested in Soleb und elsewhere, with the Hebrew form of the name of God. One might consider the missing final $<h>$, but this may not have been considered as distinctive, since it is positioned in the absolute final position. Similar phenomena are attested with the representation of other words. ${ }^{95}$ The plausibility of Manfred Görg's ${ }^{96}$ suggested etymology from the name of a bird (of prey) must be valued by scholars of Hebrew.

\subsection{Additional attestations of the Tetragrammaton in Egyptian sources}

Kurt Sethe, in his study on "traces of the Persian rule," translated the place name $p$ 3- $t$ 3 $Y$ - $h$ - $t$ of the stele Berlin 1107 as "the land of the Jews." 97 Henri Gauthier included it without further discussion as the possible writing of $Y$ - $h=$ Jahwe (Yнwн) into his Dictionnaire Géographique, ${ }^{98}$ and Jean Leclant quoted it in 1963 as a parallel for the " $Y-h-w$ " of the Soleb-lists. ${ }^{99}$

Recently, Thomas Schneider referred to the personal name (4 in an Egyptian Book of the Dead papyrus (BD Princeton "Roll 5," $18^{\text {th }}$ or early $19^{\text {th }}$ dyn.). According to Schneider, the owner's name is a theophoric sentence-name in Egyptian transcription designating "My lord is the shepherd of Yah." Schneider considers Yah to be an abbreviated form of the Tetragrammaton and it is connected by him with the writings in the Shasu-sequence at Soleb and AmarahWest. ${ }^{100}$ However, his presuppositions in connection to the Soleb- and Amarah-instances, as well as his conclusions thereof, seem dubious from a methodo-

95 See for instance Hoch, Semitic Words (see n. 12), No. 7, No. 34, No. 38 or No. 41 (the written $t$ in the Egyptian form can be ignored as any $t$ still pronounced should have been written as the combination $t+w$ or by the sign $t j$ ). The instances given contain only examples considered absolutely sure by Hoch.

96 Görg, "YHWH - ein Toponym" (see n. 7 and 16), 13-14.

97 However, Sethe, who pointed out that writing, was unable to substantiate this claim any further, see Sethe, Perserherrschaft (see n. 66), 128-129.

98 H. Gauthier, Dictionnaire des noms géographiques contenus dans les textes hiéroglyphiques I (Cairo 1925), 171 (Stele Berlin \#1107). See also H. Schäfer, "Ein Phönizier auf einem ägyptischen Grabstein der Ptolemäerzeit,” ZÄS 40 (1902-03), 32, Taf. 1 as well as K. Sethe, UÄA II: Hieroglyphische Urkunden der griechisch-römischen Zeit (Leipzig 1904), 164 (12).

99 Leclant, "Fouilles et travaux 1961-1962" (see n. 23), 203 note 3.

100 Schneider, "The first documented occurrence" (see n. 41), 114 reasons that " $y h w$ s would be a mountainous region linked to the worship of a god named Yahweh after the place of worship. This is in agreement with passages from the Old Testament where Yahweh is said to have risen up from Seir (Edom)." The writing in Soleb/Amarah-West would thus refer not directly to the divine name but to "a place associated with his cult." 
logical point of view. Especially since his interpretation of the Soleb- and Amarah-instances follows the biblical tradition verbatim, as well as the fact that he is compelled to assume, for the sake of his argument, that the Shasu-sequence' $Y$ $h-w$ was a divine name transferred into a toponym, for which there is no evidence. ${ }^{101}$

Karl-Theodor Zauzich compiled additional (partly unpublished) attestations from Demotic sources in the expression $r m \underline{t} j h w(3)$ which he interprets as 'man from Juda.'102 However, the construction is used in Demotic word formation with toponyms (designating a place of origin, such as rmt-kmy 'man-Egypt' > 'Egyptian'), divine names (designating a devotion to or a connection with a deity, such as rmt-inp 'man-Anubis' > 'person dedicated to Anubis'), infinitives (designating a profession, such as rmt- $\underline{h} n$ 'man-row' > 'oarsman, rower') as well as 'adjectives' (designating a characteristic or virtue, such as rmt-swg 'man-stupid' > 'idiot'). ${ }^{103}$ Zauzich, however, assumes the word formation with $r m \underline{t}$ to equate an otherwise unrecognized suffix $=d a$ in the word 'Judah,' thus $r m \underline{t}-j h w=$ Jud-ean $=\mathrm{Ju}=\mathrm{da}$. Be that as it may, the data do not help to settle the question whether $j h w(3)$ designates a toponym or a divine name.

Purely into the realm of imagination belongs De Moor's idea of the identity of the Egyptian chancellor Beja (Bay) with the Biblical figure of Moses. ${ }^{104} \mathrm{He}$ extends on Knauf's idea that the Asian Beja (Bay) had used the political unrest in the aftermath of the Sea peoples' raid to flee with a group of loyal subjects to Egypt. ${ }^{105}$ According to de Moor, the final syllable -ja in Beja's (Bay's) name would represent a shortened form of the Israelite name of God.

101 Schneider, "The first documented occurrence" (see n. 41), 119 concluded "Yah would thus be the use of the later divine name as a toponym which, in its long form, is attested in Egyptian toponym lists."

102 K.-T. Zauzich, "Der ägyptische Name der Juden," in: In the Shadow of Bezalel. Aramaic, Biblical, and Ancient Near Eastern Studies in Honor of Bezalel Porten (ed. A. Botta; CHANE 60; Leiden and Boston 2013), 409-416, here 412- 413.

103 See W. Spiegelberg, Demotische Grammatik (Heidelberg 1925), §28, augmented by W. Erichsen, Demotisches Glossar (Copenhagen 1945), 247-248.

104 Similarly also A.F. Rainey in his review of de Moor, "Rise of Yahwism," JNES 60 (2001), 148 "one is confronted with impossible assumptions based on flimsy and often untenable interpretations of archaeological or philological evidence." A critical assessment of the sources on the Siptah-Beja-problem has been presented by T. Schneider, "Siptah und Beja: Neubeurteilung einer historischen Konstellation,” ZÄS 130 (2003), 134-146.

105 An overview of de Moor's argumentation as well as some counter arguments can be found in Hess, "The Divine Name” (see n. 1), 182. 


\section{Town, land or mountain? Topographical consideration about the Egyptian evidence}

All scholars who have studied the Shasu-sequence have agreed so far in considering the first two elements (i.e. $t 3 \check{3} 3 s w$ ) as an ethno-geographical instead of a political designation, with the element "land" (i.e. $t$ ) referring to the vast and infinite conception of nomadic space. ${ }^{106}$ The problems arise when turning to the respective specification that follows $T 3 \breve{s} 3 s w$. As in none of the instances a determinative (such as one for a tribe, one to discriminate between an alien or a cultivated country, etc.) follows the specification, any learned speculation about an Egyptian understanding of the individual designations is moot.

The motivations for designations are specific to a given culture and are thus rather variegated. Prerequisite for the reconstruction of the history of designations of a specific name, would be an exact and continuous knowledge about the decisive factors of that culture's practice of appointing terms to things and concepts. From what is known about Egypt, the Levant, and Mesopotamia, the Shasu-names (and thus also $Y-h-w$ ) might have been derived from divine, personal, group or tribal, place, scenic, mountain, or homestead names. In addition, it seems possible that certain names lost their original designative background due to the exodus/expulsion of the group that appointed the designation, and thus gave way for a change of meaning or popular etymologies. ${ }^{107}$ The toponomastic (not topographical) possibilities of interpretation the sparse Egyptian data allow for, are much too limited for far-reaching conclusions on the history of names, or on the religious and settlement history.

Most non-Egyptological scholars assume tacitly that the Egyptian writing $Y$ $h-w$ represents the Israelite name of God, rather than the designating of a place name, as in the present case. ${ }^{108}$ Since any indicators in favour of an interpretation as a divine name are lacking, scholars have tried to avoid the resulting pit-

106 See Goedicke, “The tetragramm in Egyptian?” (see n. 21), 24 ("It denotes in a rather general fashion, land inhabited by wandering people without implying borders or social structures"). 107 Similarly in Herrmann, "Gottesname" (see n. 41), 83-84 in connection to the "history of designation" of the "Shasu Jahwe".

108 Grdseloff, "Édôm” (see n. 2), 81-82 speaks of "l'existence d'une ville Jahwa en territoire kénite, ce qui rend l'origine kénite du culte de Jahwa encore plus probable.” and Giveon, “Toponymes ouest-asiatiques à Soleb" (see n. 32), 28 assumed that the name should be interpreted as "Beth Yahwe, la maison de Yahwe," which in return designates "une ville avec un sanctuaire dans la meme region." 
falls by postulating an identification of a divine and settlement or terrain name (town, area or mountain name), for which again no proof has been presented.

Grdseloff connected the attestation of the word $Y-h-w$ in the hieroglyphically written Shasu-sequences with the Israelite name of God, and concluded that it stood for a settlement or cult centre of a clan of YHwH-devotees. ${ }^{109}$ Instead Görg wavered undecided between considering it a "regional or a tribal name" not dismissing the third option, to derive the Egyptian $Y-h-w$ from the Israelite name of God, paralleling it with the attested use of the name Assur as a tribal, country, and divine name. ${ }^{110}$ Jean Leclant attributes only a "qualité de nom de lieu" (Yнwн) to the name hieroglyphically attested at Soleb and Amarah-West. ${ }^{111}$

A more detailed picture was envisaged by M. Astour assuming that "( $\mathrm{t}$ )he Shasu districts of Soleb- 'Amarah must be understood as areas inside the cultivated territory of Syria, in which nomads were permitted to establish permanent or seasonal camps.” Thus, the Shasu-designations would have been derived from places or settlements that were - as regional centres - located near these "seasonal camps." A derivation from natural landmarks such as wells, etc. would then also be possible. Unanswered, not only in Astour's case, remains the question whether the Shasunames are indigenous or foreign designations. Especially with Astour's suggested identification (see above), one would assume a sedentary group to designate a pasture that was temporarily provided to nomadic tribes. ${ }^{112}$

\section{Conclusion}

Even after decades of heated debates about the identification and localisation of the instances discussed above, scholarship has not advanced much further than where it was after Astour's and Herrmann's critical evaluations of the evidence: - Despite the phonologically possible match between the hieroglyphic $Y-h-w$ in Soleb and Amarah-West, and what one might expect as rendition of the Tetragrammaton in hieroglyphs. The attribution to possible “(proto-)Israelites" re-

109 This rather imaginative notion is also the base of in Ahituv's explanation in Canaanite Toponyms (see n. 8), 122 according to him "(t)he šssw-land of Jahu (Yāhū) is the wandering area of the clan of the worshippers of Yāhū, the God of Israel. It most probably pertains to the region of Kadesh-barnea and Jebel Hilāl, which might be the sacred Mt. Sinai."

110 Görg, "Jahwe - ein Toponym?” (see n. 7), 187.

111 Leclant, "Le "tétragramme”" (see n. 19), 217.

112 de Moor, Rise of Yahwism (see n. 89). 
mains hypothetical, since reliable facts about the historical linguistic and cultural background for $Y-h-w$ at Soleb and Amarah-West are not available. ${ }^{113}$

- The Egyptian instances cannot be exploited for the question of YHwH's origin in the south, as the geographical context, and especially the ordering principle of the geographical list that contains them, are not clarified..$^{114}$

- In addition, it remains unclear whether $Y-h-w$ (as well as the other Shasunames) designates a tribe, an area/region or a settlement. Similarly, no clear indication for the derivation from the divine name (and vice versa), and the assumption that the divine name should be considered also as a tribal or settlement name (sanctuary or shrine), as with the above mentioned Assur, have come to the fore. ${ }^{115}$

- The spatial connection of the Shasu-names at Soleb and Amarah-West into a continuous territory is purely speculative. Neither the extension of the Shasu-areas nor their respective locations to each other can be identified based on the Egyptian lists. It is possible, but cannot be proven, that the Shasu-names that follow in the Amarah-West-list after the place name identified as Sëir, are subordinate to the latter. ${ }^{116}$

- Finally, the localisation of Sëir $\left(\hat{S}-e_{-} r-r\right)$, that is essentially connected to $Y-h$ $w$, is not without difficulties. Thus, the location of the Sëir-lands in the $18^{\text {th }}$ dynasty still needs to be clarified. ${ }^{117}$

Many scholars' euphoria and their associated expectations often hampered a critical evaluation of the Egyptian attestations. The interpretation of the sources was adjusted to an event horizon based on a predisposition influenced by the

113 See S. H. Horn, “Jericho in a Topographical List of Ramesses II,” JNES 12 (1953), 201-203, here 201: "Whether one of the Edomite tribal names bearing the name Yahweh (...) implies that Edomites were followers of the god Yahweh, or whether the name of the tribe has only a curious coincidence with the name of the Israelite god, is still undecided;" similarly sceptical is also K. A. Kitchen, Ramesside inscriptions. Translated \& Annotated. Notes and Comments 2 (Oxford 1999), $128-129$.

114 Thus also H. Pfeiffer, Jahwes Kommen von Süden, Jdc 5, Hab 3, Dtn 33 und Ps 68 in ihrem literatur- und theologiegeschichtlichen Umfeld (FRLANT 211; Göttingen 2005), 261.

115 In addition, it cannot be excluded that the Egyptian writing refers to the divine name - for a different view see M. Weippert, Jahwe und die anderen Götter: Studien zur Religionsgeschichte des antiken Israel in ihrem syrisch-palästinischen Kontext (FAT 18; Tübingen 1997), 40-41. Weippert considered it as definite that it must be "eine geographische und/oder ethnische Bezeichnung."

116 Unclear as well is the connection of the Shasu-names at Soleb and Amarah-West to the "lands of Sëir" in EA 288, 26; see M. Köckert, "Wandlungen Gotts im antiken Israel," BThZ 22 (2005), 20 note 43.

117 See Köckert, "Wandlungen Gotts im antiken Israel” (see n. 115), 3-36, here 20 note 43. 
Old Testament tradition, and was thus made fit into the topography transmitted in the Old Testament for the existing biblical scholarly narrative.

Also, the historiographic utilization of the Egyptian attestation calls for utter care. Various detail studies of the lists attested in Egyptian temples showed that the majority of the names in the Ramesside-lists, and presumably also a part of the Nubian-lists at Soleb and Amarah-West/Aksha, go back to templates of the early or middle $18^{\text {th }}$ dynasty. ${ }^{118}$ Considering the far-ranging conclusions that have been, and are drawn, based on the few $Y-h$-w-attestations that have been summarized above, the chronology of the Egyptian evidence and its transmission history should be focused upon in the future.

118 The question of the date of the template or the "Urliste" of the lists at Soleb, Amarah-West, and Medinet Habu should be considered for the issue at hand here. Doubts about the authorship of Amenhotep III. for the lists at Soleb and Amarah-West have been uttered already by H.W. Fairman, "Review of Simons, Handbook," JEA 26 (1940), 165 and Horn, "Jericho in a Topographical List of Ramesses II” (see n. 112), 202. Also Giveon, “Toponymes ouest-asiatiques à Soleb” (see n. 32), 254-255, opted for a redaction under Thutmosis III. or Amenhotep II. (maybe even Thutmosis I.) based on historical and graphemic considerations. A similar opinion was expressed by Helck, "Die Bedrohung Palästinas" (see n. 68), 478: "Diese Liste ist sicher nicht aus der Zeit Amenophis' III., sondern älter und mag auf einen früheren Feldzug zurückgehen, etwa auf Thutmosis' II. (Urk. IV 36, 13) oder den Thutmosis’ III. in seinem 39. Jahr (Urk. IV 721, 12).” 
Brought to you by | Universitaetsbibliothek Basel

Authenticated

Download Date | 12/18/17 11:19 AM 